\title{
Paranasal sinuses and human identification
}

\author{
Seios paranasais e identificação humana \\ Senos paranasales e identificación humana
}

Received: 07/12/2021 | Reviewed: 07/19/2021 | Accept: 07/23/2021 | Published: 07/31/2021

Franciéllen de Barros

ORCID: https://orcid.org/0000-0001-5460-4334

São Paulo State University, Brazil

E-mail: fran.dbrs@gmail.com

Clemente Maia da Silva Fernandes

ORCID: https://orcid.org/0000-0002-5401-6265

São Paulo State University, Brazil

E-mail: c.face@terra.com.br

Barbara Kuhnen

ORCID: https://orcid.org/0000-0003-2586-4772

São Paulo State University, Brazil

E-mail: kuhnenbarbara@gmail.com

José Scarso Filho

ORCID: https://orcid.org/0000-0002-8633-1120

São Paulo State University, Brazil

E-mail: jose.scarso@icloud.com

Marcelo Gonçalves

ORCID: https://orcid.org/0000-0002-4548-7751

São Paulo State University, Brazil

E-mail: marcelo.goncalves1970@unesp.br

Mônica da Costa Serra

ORCID: https://orcid.org/0000-0001-8820-2982

São Paulo State University, Brazil

E-mail: monica.serra@unesp.br

\begin{abstract}
The characteristics of the paranasal sinuses (maxillary, frontal, sphenoid and ethmoid sinuses) are information of great relevance to Forensic Sciences, as their images can be used for human identification purposes. Due to their particularities, the paranasal sinuses provide valuable information for human identification, reducing the risk of errors during investigation by experts. Such structures are visualized from several imaging exams. This study evaluates the possibilities of human identification through the analysis of the paranasal sinuses, as well as the effectiveness of their analysis in estimating sex, age and ancestry. A comprehensive search was performed in the PubMed, SciELO, LILACS, and Web of Science databases. As inclusion criteria, texts that addressed the subject were selected. Imaging analysis of the frontal, maxillary and sphenoid sinuses is a useful tool for human identification, as well as for estimating sex, age and ancestry; usually provides a high level of accuracy. Regarding the ethmoid sinus, research is indicated to verify its use in human identification, as no publications on this specific subject were found. Additional research must be carried out (especially three-dimensional analysis of the paranasal sinuses), to develop standardized protocols, improving the work of experts, helping justice and society.

Keywords: Forensic sciences; Human identification; Forensic anthropology; Forensic dentistry; Forensic imaging and radiology; Paranasal sinuses; Frontal sinus; Maxillary sinus; Sphenoid sinus; Ethmoid sinus.

\section{Resumo}

As características dos seios paranasais (seios maxilares, frontais, esfenoidais e etmoidais) são informações de grande relevância para as Ciências Forenses, pois as suas imagens podem ser utilizadas para fins de identificação humana. Devido às suas particularidades, os seios paranasais fornecem informações valiosas para a identificação humana, diminuindo os riscos de erros durante a investigação pelos peritos. Tais estruturas são visualizadas a partir de vários exames imaginológicos. Este estudo avalia as possibilidades de identificação humana por meio da análise dos seios paranasais, bem como a efetividade da análise dos mesmos na estimativa do sexo, idade e ancestralidade. Uma busca abrangente foi realizada nas bases de dados PubMed, SciELO, LILACS e Web of Science. Como critérios de inclusão foram selecionados textos que abordavam a temática. A análise imaginológica dos seios frontal, maxilar e esfenoidal é uma ferramenta útil para a identificação humana, bem como para estimativa de sexo, idade e ancestralidade; geralmente fornece um alto nível de precisão. Em relação ao seio etmoidal, são indicadas pesquisas para verificar seu uso na identificação humana, pois não foram encontradas publicações sobre este mote específico. Pesquisas adicionais devem
\end{abstract}


ser realizadas (especialmente análises tridimensionais dos seios paranasais), para desenvolver protocolos padronizados, melhorando o trabalho dos peritos, auxiliando a Justiça e a sociedade.

Palavras-chave: Ciências forenses; Identificação humana; Antropologia forense; Odontologia legal; Imaginologia e radiologia forense; Seios paranasais; Seio frontal; Seio maxilar; Seio esfenoidal; Seio etmoidal.

\section{Resumen}

Las características de los senos paranasales (maxilar, frontal, esfenoides y etmoides) son información de gran relevancia para las Ciencias Forenses, ya que sus imágenes pueden ser utilizadas con fines de identificación humana. Por sus particularidades, los senos paranasales proporcionan información valiosa para la identificación humana, reduciendo el riesgo de errores durante la investigación por parte de expertos. Estas estructuras se visualizan a partir de varios exámenes por imágenes. Este estudio evalua las posibilidades de identificación humana a través del análisis de los senos paranasales, así como la efectividad de su análisis en la estimación de sexo, edad y ancestralidad. Se realizó una búsqueda exhaustiva en las bases de datos de PubMed, SciELO, LILACS y Web of Science.Como criterio de inclusión se seleccionaron textos que abordaban el tema. El análisis imaginológico de los senos frontal, maxilar y esfenoidal es una herramienta útil para la identificación humana, así como para estimar el sexo, la edad y la ancestralidad; generalmente proporciona un alto nivel de precisión. En cuanto al seno etmoidal, está indicada la investigación para verificar su uso en la identificación humana, ya que no se encontraron publicaciones sobre este tema específico. Se deben realizar investigaciones adicionales (especialmente análisis tridimensional de los senos paranasales), para desarrollar protocolos estandarizados, mejorando el trabajo de los expertos, ayudando a la justicia y la sociedad.

Palabras clave: Ciencias forenses; Identificación humana; Antropología forense; Odontología forense; Radiología e imagenología forense; Senos paranasales; Seno frontal; Seno maxilar; Seno esfenoidal; Senos etmoidales.

\section{Introduction}

The identity of a person corresponds to a set of physical, functional or psychological, and normal or pathological characteristics, making the individual identical only to himself. The identification process is complex, systematic, and organized, and the main objective is to determine the identity of the individual in evidence. It is a comparative process, meaning it necessarily needs to compare data knowingly from an individual with the corresponding data from the subject to be identified (Neves et al., 2021; Andrade et al., 2021; Barros et al., 2021a; Gioster-Ramos et al., 2021; Kuhnen et al., 2021; Barros et al., 2021b; France, 2017; Xavier et al., 2015; Nikam et al., 2015). However, this is a challenging task for mankind although of great importance, because besides dealing with humanitarian issues, it also directly impacts civil and criminal proceedings (Dostalova et al., 2012).

Decomposing, skeletonized, or charred corpses, especially in large-scale accidents, usually need to be identified, requiring the use of anthropological methods (Singh et al., 2013). This occurs particularly when there is no suspicion about the identity of the deceased, which often requires assessing the biological profile of the subject.

In the absence of ante-mortem data leading to personal identities, the biological profile helps to reduce the number of suspects investigated using identification methods (Passalacqua, 2009; Klales, Kenyhercz, 2015).

Identification methods have a comparative characteristic between ante-mortem and post-mortem data. According to Interpol (2018), the primary methods are fingerprint analysis, DNA verification, and Forensic Dentistry (Fernandes, 2010). However, for these methods to be valid they must fulfill some requirements such as immutability, uniqueness, practicability, permanence, and classifiability (França, 2017).

The use of anthropological methods is necessary when bodies that require identification are found (Singh et al., 2013) but there is no suspicion about the identity of the subjects. To determine individual characteristics, aiding the identification process, it is timely to analyze the bones of the skull, pelvis, and femur, as well as the sella turcica, mastoid cells, and paranasal sinuses (Cox et al. 2009).

Due to the particularity of their contours, paranasal sinuses provide valuable information for human identification, reducing the risk of errors by forensic professionals during the investigation (Barros et al., 2021b; Gioster-Ramos et al., 2021; Musse, 2009). Paranasal sinuses are arranged in the two facial hemispheres and classified, according to their anatomical 
relationships, into maxillary sinus (MS), ethmoid sinus (ES), frontal sinus (FS), and sphenoid sinus (SS) (Keir, 2009; Gallup, Hack, 2011; Ebrahimnejad et al., 2016).

Several imaging tests such as Waters and panoramic radiographs, Computed Tomography (CT), Magnetic Resonance Imaging (MRI), and Cone-Beam Computed Tomography (CBCT) can provide the visualization of paranasal sinuses, but recently CBCT has become an adequate imaging method for analyzing sinuses due to its higher resolution, lower radiation, and lower cost than traditional CT (Scarfe et al., 2006). Furthermore, due to the characteristics of their contours and the comparison between the data obtained by imaging methods, paranasal sinuses can provide information for forensic identification (Lee et al., 2004).

This study evaluates the possibilities of human identification through the analysis of paranasal sinuses, as well as the effectiveness of their analysis in estimating sex, age, and ancestry.

\section{Methodology}

This study was based on a descriptive literature review with a qualitative approach (Pereira et al., 2018), constituting an extensive study and allowing the inclusion of experimental and non-experimental research and theoretical and empirical literature to deepen the knowledge on the subject studied. A comprehensive search was performed in the PubMed, SciELO, LILACS, and Web of Science primary databases. The descriptors used were "paranasal sinus", "frontal sinus", "maxillary sinus", "ethmoid sinus", "sphenoid sinus", "human identification", "radiographic images", "cone-beam computed tomography", "threedimensional images ", "sex", "age", and "ancestry". Initially, the descriptors were searched individually, and then crossings were made between them. The sample was selected by including articles, dissertations, and theses that were available in full, published in Portuguese or English, at any period, and referred to the topic studied. Exclusion criteria were texts published in languages other than English and Portuguese and not related to the topic studied. The research was classified and evaluated, ending with the interpretation of results and synthesis of knowledge. This article also has a theoretical and reflective approach on the biological profile characteristics that contribute as an auxiliary forensic method of human identification through the analysis of paranasal sinuses.

\section{Results and Discussion}

\subsection{Anatomy and embryology of paranasal sinuses}

Positioned in the bones that comprise the nasal cavity, paranasal sinuses are named according to anatomical relationships as maxillary sinus, ethmoid sinus, frontal sinus, and sphenoid sinus (Keir, 2009; Gallup, Hack, 2011; Ebrahimnejad et al., 2016). As they are composed of air, they are classified as pneumatic cavities and lined by the mucoperiosteal membrane covered by the ciliated cylindrical pseudostratified epithelium, determining a direct or indirect communication with the respiratory system. They can ensure the harmony of facial growth and lighten the skull, protecting infraorbital and intracranial structures, protecting against injuries, and partially neutralizing impacts (Batista et al., 2011).

For Orhan et al. (2017), due to their location, the sinuses cooperate to the development of facial structures, jaws, and upper airways; humidification and heat of inspired air; thermal insulation; increased voice resonance; cranial structure weight; and expansion of olfactory surfaces. Additionally, sensitive structures are insulated from the rapid fluctuations of temperature in the nose. Paranasal sinuses also help to improve nasal function and nitric oxide production, which contribute to nasal immune defense (Keir, 2009).

The nasal cavity is a roughly cylindrical midline airway that extends forward from the wing of the nose to the posterior nostril. On each side, it is surrounded by the maxillary sinus and covered by the frontal, ethmoid, and sphenoid sinuses, front to back. Although it seems simple, the nasal anatomy is composed of complex and subdivided airways connecting to the sinuses. 
The four paranasal sinuses paired and aligned with the pseudostratified columnar epithelium are 1. maxillary sinus: the largest sinus, located in the maxilla; 2. frontal sinus: located above the eyes, inside the frontal bone; 3. ethmoid sinus: several discrete air cells in the ethmoid bone between the nose and eyes; 4. sphenoid sinus: located within the sphenoid bone (Cappello et al., 2020).

\subsubsection{Maxillary sinus}

In the embryonic period, the alveolar processes are close to the orbital edge, which contains tooth germs. The lateral wall of the nasal cavity is membranous, starting an invagination in the middle meatus region, forming a sinus sac toward this maxillary region and located medially to it. At birth, the maxillary sinus (MS) is small and located medially to the orbit. When children are born, they have a rudimentary slit-shaped ethmoidal labyrinth and maxillary sinus. The MS develops up to fifteen years of age. In the first year of life, the maxillary sinus descends from the orbit without reaching the infraorbital nerve canal. After sinus pneumatization, in the second year, it reaches the canal and surpasses it in the following two years. The entire development of the maxillary sinus depends on teeth eruption and ends when the permanent dentition descends, including the third molar. It is worth noting that the floor of the maxillary sinus of children is higher than the floor of the nasal cavity and as high as the middle meatus. Only at nine years old the floors of the maxillary sinus and the nasal cavity are aligned (Physiology and Endoscopic Nasosinusal Anatomy, 2011).

The dimensions of the MS vary individually, but on average, the base in an adult is $35 \mathrm{~mm}$ and the height is $25 \mathrm{~mm}$ (Raja, 2009). These measures vary according to age, ancestry, sex, and personal conditions. Maxillary sinuses are presented in pairs, located in the body of the jaws, and on both sides. They have a square pyramid shape with the bottom facing the lateral wall of the nasal cavity. The apex corresponds to the junction of the maxillary zygomatic process with the zygomatic bone and, in some cases, extending internally. The apex is usually located $25 \mathrm{~mm}$ from the base. The sides of this pyramid refer to the following maxillary surfaces: the upper wall or the top of the maxillary sinus corresponds to the orbital aspect of the maxilla, on the floor of the orbit; the front wall corresponds to the anterior surface of the maxilla; the posterior wall corresponds to the infratemporal aspect of the maxilla and separates the sinus from the infratemporal fossa; and the inferior wall or inferior part of the maxillary sinus corresponds to the alveolar process of the maxilla (Batista et al., 2011).

According to Pfaeffli et al. (2007), the MS radiography used to recognize individuals can be considered a complementary examination, providing relevant data to professional knowledge with standardized methods. For identification, the morphometric measurements of the maxillary sinus are compared with the shape, size, and contour of the images available.

The morphology and metrics of maxillary sinuses can be used to estimate sex and for human identification (Musse et al., 2009) (Musse et al., 2011). The literature reports cases of identification performed by comparing the ante-mortem and postmortem characteristics of the morphology of maxillary sinuses (Musse et al., 2011).

\subsubsection{Frontal sinus}

The frontal sinus (FS) starts to develop in the fourth or fifth week of pregnancy, continuing through adolescence or early adulthood. The FS begins as an insignificant pneumatization of the newborn and is radiologically visible around four years of age. Craniofacial growth is synchronized with the frontal sinus. (Duke, Cassiano, 2005).

Frontal sinuses are bilaterally divided by the main septum and there may be additional septa with varying sizes. They originate in the anterior part of the middle meatus (frontal recess) but they can also originate from an anterior ethmoidal cell that invades the frontal bone (Mafee, 1991; Babbel, 1991; Harnsberger et al., 1991; Laine, 1992; Scuderi et al., 1993; Nasosinusal Physiology and Endoscopic Anatomy, 2011). The FS drains through the frontal nasal canal to the frontal recess, the stenosis between the frontal sinus and the anterior middle meatus usually located in the anterosuperior portion of the infundibulum, and 
through the semilunar hiatus to the anterior part of the middle meatus, where they converge from the flow of the ipsilateral maxillary sinus. It can also drain directly into the middle meatus, above the infundibulum (Mafee, 1991; Babbel, 1991; Harnsberger et al., 1991; Laine, 1992; Scuderi et al., 1993).

The frontal sinus is undeveloped in $4 \%$ of people and its full development occurs between the ages of 10 and 12 (Hungary, 2000). The growth of the skull base and its anterior and middle fossae is centered in the sphenoid and ethmoid bones, and all neural and visceral bone architecture relates to it in anatomy and function. The interrelationships between these elements have been the basis for determining the constitutional type since childhood, and changes in this process can lead to craniofacial dysmorphisms (Mafee, 1991; Babbel, 1991; Harnsberger et al., 1991; Laine, 1992; Scuderi et al., 1993).

According to Nikam et al. (2015), both the height and the maximum width of the frontal sinus are unique characteristics of each individual. Silva et al. (2019) reported that the morphological information of frontal sinuses converges between antemortem and post-mortem radiographs for both metric and non-metric evidence, allowing to identify subjects.

Several studies have analyzed frontal sinus images for human identification, such as Silva et al. (2008), Falguera et al. (2008), Silva et al. (2009), Besana et al. (2010), David and Saxena (2010), Patil et al. (2012), Kim et al. (2013), Beaini et al. (2015), among others. Using CBCT as an imaging method, Marques et al. (2014), Cossellu et al. (2015), and Soares et al. (2016) described the use of the frontal sinus for human identification in forensic investigations.

Therefore, Zhao et al. (2021) developed standardized techniques to classify the frontal sinus according to its 3D morphological measurements and found the usefulness of the 3D model in identifying the Han Chinese population. Pereira et al. (2021) performed a systematic literature review to verify the existing methodological techniques, showing the advantages and limitations of the frontal sinus morphological assessment for human identification through two-dimensional or three-dimensional images of the maxillofacial region. According to the research, most studies showed a low risk of bias. Li et al. (2021) explored an innovative procedure for assessing the individuality of the frontal sinus based on a 3D-3D overlay procedure for comparative forensic identification.

\subsubsection{Sphenoid sinus}

The sphenoid sinus (SS) develops from the third month of pregnancy. During this period, the nasal mucosa invades the posterior part of the cartilaginous nasal capsule, forming a pouch-like cavity. In the last few months of fetal development, the wall around the cartilage ossifies. In the second and third years of life, the cartilage is reabsorbed and the cavity is fixed to the sphenoid body. At around six or seven years of age, the vaporization of the sphenoid sinus progresses and, by the age of 12 , its pneumatization is completed, with pneumatization of anterior clinoids and the pterygoid process (Cappello et al. 2020).

In the first years after birth, the SS originates from the invagination of the mucosa to the sphenoethmoidal recess, continuing its pneumatization process by invading the sphenoid bone until puberty (Endoscopic Nasosinusal Anatomy and Physiology, 2011).

Sphenoid sinuses are the most posterior of the paranasal sinuses. They are usually "immersed" in the cleft and are limited in the upper back by the sella turcica. Their ostia are positioned medially in the anterosuperior portion of the anterior wall of each sinus, communicating with the sphenoethmoidal recess in the posterior part of the superior meatus. The sphenoethmoidal recess appears lateral to the nasal septum and can sometimes be seen on CT images in coronal slices, but is best seen in sagittal or axial slices (Babbel, Harnsberger, 1991; Harnsberger et al., 1991; Scuderi et al., 1993; Zinreich, 1998).

Auffret et al. (2016) evaluated the validity of the anatomical visual comparison of the CT of sphenoid sinuses in forensic identification. According to the authors, this sinus is useful because identification accuracy was $100 \%$.

Thus, the anatomical individuality of this sinus can be validly applied in forensic contexts for human identification (Capella et al., 2019). 


\subsubsection{Ethmoid sinus}

The ethmoid sinus (ES) originates from the invagination of the mucosa of the middle and superior meatus and is located between the maxillary sinus, the eyeball, and the brain. Its growth is allowed by the fovea ethmoidalis and, depending on the development of the cribriform plate and the roof of the ethmoidal bone at birth, the volume of all its cells is similar to that of the maxillary sinus. Anterior ethmoid cells reach the same height as the superior orbital ridges at five years of age (Endoscopic Nasosinusal Physiology and Anatomy, 2011).

There are three to four cells at birth and 10 to 15 cells in adulthood, with a total volume of 2 to $3 \mathrm{ml}$, which are located between the eyes. The anterior ethmoids drain into the ethmoid infundibulum, in the middle meatus. The posterior ethmoid sinus drains into the sphenoethmoidal recess in the upper nasal passage. The ES is supplied by the anterior and posterior ethmoid sinus arteries, which are branches of the ophthalmic artery. The ophthalmic artery is a branch of the internal carotid artery (Cappello et al. 2020).

The ethmoid sinus is usually the most complex of the paranasal sinuses, with a highly variable anatomical structure and a close relationship with the orbit and the base of the skull. The first ES cell found is the ethmoidal bulla, which is located behind the semilunar hiatus and in front of the basal lamella. It is a circular structure with the side attached to the papyraceous lamina (Kuan, Palmer, 2021). The ethmoid sinus is composed of many thin-walled air cells, some of which may extend forward between the lacrimal sac and the nasal mucosa (Nerad, 2021).

\subsection{Paranasal sinuses and human identification}

Due to their characteristics and contours, paranasal sinuses can provide valuable information for human identification through detailed and clear analyses, reducing the risk of errors by the expert in the investigation process.

The radiological assessment of paranasal sinuses and related structures is designed to accurately describe the anatomical area and confirm any skeletal changes or changes in the sinus mucosa and fluid level, and determine the existence and extent of pathologies (Fatterpekar et al. 2008; Ritter et al., 2011).

Several authors have evaluated the maxillary, frontal, and sphenoid sinuses, relating them to possibilities of human identification with extraoral radiographs (Riepert et al., 2001; Pfaeffli et al., 2007; Silva et al., 2009) and CT scans (Perella et al., 2003; Pfaeffli et al., 2007; Tatlisumak et al., 2008; Uthman et al., 2010). Gioster-Ramos et al. (2021) point out that the uniqueness of their structures individualizes people, thus paranasal sinuses can be used for human identification. Currently, the use of CT allows three-dimensional analyses, which greatly enriches and increases the resources available from Forensic Sciences and helps justice and society to establish the human identity.

Ruder et al. (2012) assessed the reliability of radiological identification through the visual comparison of CT of paranasal sinuses before and after death and confirmed that the visual comparison of CT of the skull is a robust and reliable method to identify unknown cadavers.

For many years, traditional radiographs were used to study sinuses (Cagici et al., 2005). However, due to overlapping, two-dimensional radiographic images are difficult to interpret (Liang et al., 2010). Conversely, with technological advances, CBCT has become a valuable method for evaluating sinuses because interactive and three-dimensional images have a great impact on head images, improving the ability of professionals to accurately describe the condition and location of sinuses (Cakli et al., 2012; Poorey, Gupta, 2014).

\subsection{Paranasal sinuses for estimating the biological profile: sex, age, and ancestry}

The study of anthropometry is essential to clarify issues related to human identification for being highly important for linear and angular measures and measuring the area and volume of different parts of the body (Garcia, 2014). The anthropometric 
analysis of bones provides basic characteristics of the individual, such as sex, age at death, ancestry, and height (Fernandes, 2010).

In the forensic context, the construction of the biological profile with individual characteristics is important. When unknown bodies are found and taken to the Forensic Medical Institute, forensic anthropologists initially estimate sex and age at death (Kim et al., 2006). Ancestry and stature are variables that, along with the previous two, constitute the so-called biological profile of an individual.

Some authors developed studies with paranasal sinuses to estimate sex, age, and ancestry (Camargo, 2000; Garcia, 2014; Sidhu et al., 2014; Saccucci et al., 2015; Araújo et al., 2015; Moore. Ross, 2017; Rani et al., 2017; Özer et al., 2018; Demiralp et al., 2019; Najem et al., 2020; Robles et al., 2020).

A comprehensive description of sex based on skeletal characteristics is a basic step in forensic investigations (Franklin et al., 2006; Franklin et al., 2008). For Carvalho (2012), estimating the sex of an individual is one of the most important analyses in human identification processes. To determine sexual dimorphism across the skull structure, a visual comparison of bones or measurement of cranial components can be performed.

Age estimation in forensic clarification is important, as it helps to identify corpses and classify individuals into capable and absolutely and relatively incapable, which information has an important forensic function (Schmidt, 2004).

Ancestry estimation is performed through morphological characteristics and bone measurements, which facilitates compatibility with established ancestral groups (Ousley et al., 2009). However, the presence and maintenance of bone elements are required for morphological or metric analyses, as well as for assessing the age and sex of individuals (Batista, Santos, 2018).

Brazil has a mixed population, which makes it difficult to determine the biological characteristics (biological profile) of the ancestral pattern when comparing foreign populations with their anthropometric characteristics and differences. Therefore, to obtain reliable information, forensic anthropologists must prudently use protocols and methods (Almeida Júnior et al., 2010), especially those developed with parameters obtained from studies with other populations.

Among the parameters for estimating biological characteristics, ancestry is the most difficult, researched, and controversial (Vanrell, 2019). Due to the scarcity of research in this area, especially in highly mixed populations such as Brazil, its estimation is a challenge (Batista, Santos, 2018).

The $\mathrm{CT}$ is described as one of the potential imaging methods that can help forensic professionals to identify the human body, especially CBCT (Phothikhun et al., 2012; Hishmat et al., 2014; Silveira, 2015). Regarding paranasal sinuses, these methods allow accurate assessments and analyses (Pfaeffli et al., 2007; Tucunduva, Freitas, 2008). There are several studies in the literature that used radiographic images to verify whether the frontal, maxillary, and sphenoid sinuses provide support for recognition in estimating sexual dimorphism, age, and ancestry. As for the ethmoid sinus, no data were found relating it to these variables.

However, Robles et al. (2020) performed a study to propose a new method to determine biological characteristics with the three-dimensional (3D) reconstruction of paranasal sinuses to estimate age, sex, and ancestry. The findings of this study provide insights into the potential of using paranasal sinuses as an attribute to distinguish individuals and identify unknown human remains in forensic investigations.

Thus, in 2017, Sherif et al. determined the accuracy of using paranasal sinuses measurements as a method of estimating sex with multi-detector computed tomography. According to the results, the maxillary sinus presents the highest precision in estimating sexual dimorphism, followed by the frontal sinus and sphenoid sinus, and concluding the effectiveness of its use for human identification.

Demiralp et al. (2019) analyzed CBCT images of a sample of ancient skulls to determine whether the dimensions and volume of paranasal sinuses could be useful to identify the estimate of sex and age. The results did not show statistically 
significant differences between measurements $(\mathrm{p}<0.05)$ and the authors concluded that the measurements of volume and dimensions of the sinus from CBCT data can be a promising technique for determining sex and age.

Some studies, such as by Sidhu et al. (2014), Garcia (2014), Kanthem et al. (2015), Araújo et al. (2015), Tambawala et al. (2016), Prabhat et al. (2016), Bangi et al. (2017), Paknahad et al. (2017), Farias Gomes et al. (2019), Mohamed et al. (2020), Sathawane et al. (2020), and Soares et al. (2020) verified the accuracy and reliability of the maxillary sinus in sexual estimation and the results of all of them showed that this sinus can be used for such a purpose.

Likewise, Teixeira et al. (2020) evaluated, with CBCT, whether the maxillary sinus can be used to estimate sex and age. All measurements were greater in men and, regarding age, the youngest group had greater height measurements. According to the authors, the measurement of the maxillary sinus in CBCT images can be applied to sexual dimorphism in a complementary way, but for age estimation, the use of the maxillary sinus was less accurate.

The study by Araújo et al. (2015), using CBCT images, also had important implications for sex estimation, as it presented a statistically significant difference $(\mathrm{p}=0.0005)$ between the sexes, with a greater volume of MS observed in male individuals. However, regarding ancestry, it did not find a significant difference $(\mathrm{p}=0.4535)$ for brown and white individuals. Similarly, Soares et al. (2020) analyzed CBCT images and investigated sexual dimorphism in the Brazilian population, as well as the possibility of human identification through the maxillary sinus. The results show significant differences between the sexes. It was concluded that the evaluation of morphological and dimensional parameters of the MS are reproducible and thus considered valid for human identification.

In the same sense, Faria Gomes et al. (2019) developed and validated a formula to estimate sex with measurements of maxillary sinuses, using CBCT in a Brazilian population. The measurements of maxillary sinuses were significantly greater in men, with height being the most dimorphic measure and presenting an accuracy of $77.7 \%$ for sex estimation, which can be a complementary method for human identification in the Brazilian population. The data obtained in the study by Uthman et al. (2011) also found a relationship between sex and measurements of the maxillary sinus. These authors analyzed reconstructed helical CT images and studied the accuracy and reliability of MS measurements for sex estimation, obtaining positive outcomes for the use of MS in the study of sexual dimorphism, with an overall accuracy of 71.6\%.

The study by Najem et al. (2020) showed a divergent result. To estimate sex and age, these authors used CBCT images and performed linear measurements of the maxillary sinus. The results showed that the sample studied did not present statistically significant differences in the measurements, which could not be used to determine such parameters. The same occurred in the study by Etemadi et al. (2017). These authors evaluated the volume of the maxillary sinus with CBCT and analyzed its association with sex and some craniofacial indices. The average volume of the MS was higher in men. However, this parameter cannot be used for sex estimation because the area under the receiver operating curve (ROC) was 62.7\%. The study by Gulec et al. (2020), performed with CBCT in a Turkish subpopulation, was also contradictory, as the authors did not find a relationship of MS volume with sex and age.

Using magnetic resonance imaging, Rani et al. (2017) estimated age and sex with the size and volume of the maxillary sinus. The results showed sexual dimorphism and a statistically significant difference. There were no statistically significant differences for the estimated age.

Regarding the characteristics of the frontal sinus, Camargo (2000) concluded that the morphological analysis (area and perimeter) of this sinus can help to estimate sex. Likewise, Xavier et al. (2015) concluded that the FS is useful for human identification by conducting a literature review of 30 articles to assess the contribution of frontal and maxillary sinuses in Forensic Sciences to human identification and sex estimation. In 2017, Moore \& Ross found that the frontal sinus is valid for estimating age and accurately predicting the age of subadults (Moore \& Ross, 2017). 
Scendoni et al. (2021) implemented a study on frontal sinuses, which involved the development of a personal code using the method presented by Cameriere et al. (2020), besides the variables considered by Yoshino et al. (1987) for the personal identification of Italians, Kosovars, and Turks to test the aforementioned approach and compare the results between the three different populations. According to the authors, this method is suitable for different groups of people. When comparing frontal sinus radiographs before and after death, the possibility of identifying a person increases significantly. The results show that the model is more discriminative in identifying individuals of different nationalities. Similarly, Abdalla (2021) measured the anteroposterior length, width, and height of the FS in different age groups of both sexes with axial, coronal, and sagittal tomography. The results showed statistical differences that can have considerable value in determining the sex, age, racial origin, and ethnic group for living or dead individuals.

As for the sphenoid sinus, according to Oliveira et al. (2009), it has great individual differences in area and volume, and it can be used to assess sexual dimorphism. The results of the study by Özer et al. (2018) showed that the SS can be used to estimate the sex and age of human remains, as well as determine age-related changes and population differences. Considering the Brazilian population and the sphenoid sinus to identify individuals, Ramos et al. (2021) performed linear and volumetric measurements of the SS with CBCT and concluded that these measurements are useful to characterize the sex of individuals. However, in the study by Oliveira et al. (2017), performed with helical CT, there were no significant correlations between age, sex, and sphenoid sinus volume.

\section{Conclusion}

The imaging analysis of frontal, maxillary, and sphenoid sinuses is a useful tool for human identification, as well as for estimating sex, age, and ancestry, as it commonly provides a high level of accuracy. Along with the two-dimensional analysis of sinuses, three-dimensional images are highly relevant for human identification. Although the three-dimensional analysis is still not routine, its use in Forensic Sciences is without a doubt an excellent means provided by new technologies.

Additional research must be carried out to create standardized protocols using new technologies, especially the 3D analysis of paranasal sinuses, to improve the work of forensic professionals, assisting justice and society. Regarding the ethmoid sinus, studies must be performed to verify its use for human identification, as there is no published data on the subject.

\section{Acknowledgments}

\section{Funding}

This study was financed in part by the Coordenação de Aperfeiçoamento de Pessoal de Nível Superior - Brasil (CAPES) - Finance Code 001.

\section{References}

Abdalla, M. A. (2021). Age Differences of Human Frontal Sinus Measurements using CT Scan. J Adv Med Biomed Res., 29 (136), $293-301$.

Almeida Júnior, E., Araújo, T. M., Galvão, L. C. C. \& Campos, P. S. F. (2010). Investigação do sexo através de uma área triangular facial formada pela interseção dos pontos: forame infraorbital direito, esquerdo e o próstio, em crânios secos de adultos. Rev Ciênc Méd Biol., 9(1), 8-12.

Andrade, A. M. C., Gomes, J. A., Oliveira, L. K. B. F., Santos, L. R. S., Silva, S. R. C., Moura, V. S., \& Romão, D. A. (2021). Odontologia legal - o papel do Odontolegista na identificação de cadáveres: uma revisão integrativa. Research, Society and Development, 10, 2, e29210212465.

Araújo, R., Costa, S. T., Gamba, T. O., Daruge-Júnior, E., Francesquini-Júnior, L., Rossi, A. C. \& Prado, F. B. Análise da ancestralidade e dimorfismo sexual pelo seio maxilar em duas sub populações brasileiras miscigenadas - estudo piloto. In: Araújo R. (2015). Three-dimensional anthropometric analysis to determine the ancestry and sexual dimorphism in Brazilians individuals; study in Cone Beam Computed Tomography. Dissertação. Universidade Estadual de Campinas, Piracicaba, São Paulo, Brasil.

Auffret, M., Garetier, M., Diallo, I., Aho, S \& Ben Salem, D. (2016). Contribution of the computed tomography of the anatomical aspects of the sphenoid sinuses to forensic identification. J Neuroradiol., 43(6), 404-414. 
Babbel, R., Harnsberger, H. R., Nelson, B., Sonkens, J. \& Hunt, S. (1991). Optimization of techniques in screening CT of the sinuses. Am J Neuroradiol., 12, $849-854$.

Bangi, B. B., Ginjupally, U., Nadendla, L. K. \& Vadla, B. (2017). 3D Evaluation of Maxillary Sinus Using Computed Tomography: A Sexual Dimorphic Study. Int J Dent., 2017, 9017078.

Barros, F., Serra, M. C., Kuhnen, B., Scarso Filho, J., Gonçalves, M., \& Fernandes, C. M. S. (2021)a. Midsagittal and bilateral facial soft tissue thickness: a Cone-Beam Computed Tomography assessment of Brazilian living adults. Forensic Imaging. 200444.

Barros, F., Serra, M. C., Kuhnen, B., Matos, R. A. \& Fernandes, C. M. S. (2021)b. Orthodontic 2D and 3D frontal sinus imaging records: an important role in human identification. Research, Society and Development, 10(13), e49110313608.

Batista, A. F. N. \& Santos, B. V. A. C. (2018). O estudo da ancestralidade pelo crânio na antropologia forense: revisão de literatura. Conclusão de curso. Universidade Tiradentes, Aracaju, Sergipe, Brasil.

Batista, P. S., Rosário-Júnior, A. F. \& Wichnieski, C. (2011). Contribuição para o estudo do seio maxilar. Revista Portuguesa de Estomatologia, Medicina Dentária e Cirurgia Maxilofacial, ;52(4), 235 - 9.

Beaini, T. L., Duailibi-Neto, E. F., Chilvarquer, I. \& Melani, R. F. (2015). Human identification through frontal sinus 3D superimposition: Pilot study with Cone Beam Computer Tomography. J Forensic Leg Med., 36, 63-9.

Besana, J. L. \& Rogers, T. L. (2010). Personal identification using the frontal sinus. J Forensic Sci., 55(3), 584-9.

Cagici, C.A., Cakmak, O., Hurcan, C. \& Tercan, F. (2005). Three-slice computerized tomography for the diagnosis and follow-up of rhinosinusitis. Eur Arch Otorhinolaryngol., 262(9), 744-50.

Cakli, H., Cingi, C., Ay, Y., Oghan, F., Ozer, T. \& Kaya, E. (2012). Use of cone beam computed tomography in otolaryngologic treatments. Eur Arch Otorhinolaryngol., 269(3), 711-20.

Camargo, J. R. (2000). Estimativa do sexo, através das características radiográficas dos seios frontais. Tese. Universidade Estadual de Campinas, Piracicaba, São Paulo, Brasil.

Cameriere, R., Scendoni, R., Lin, Z., Milani, C., Palacio, L. A. V., Turiello, M. \& Ferrante, L. (2020). Analysis of frontal sinuses for personal identification in a Chinese sample using a new code number. J Forensic Sci., 65(1), 46-51.

Cappella, A., Gibelli, D., Cellina, M., Mazzarelli, D., Oliva, A.G., Angelis, D., Sforza, C. \& Cattaneo, C. (2019). Three-dimensional analysis of sphenoid sinus uniqueness for assessing personal identification: a novel method based on 3D-3D superimposition. Int J Legal Med., 133(6), 1895-1901.

Cappello, Z. J., Minutello, K., \& Dublin, A. B. (2020). Anatomy, Head and Neck, Nose Paranasal Sinuses. https://www.ncbi.nlm.nih.gov/books/NBK499826.

Carvalho, S. P. M. (2012). Estimativa do sexo em crânios da região de Guarulhos-SP utilizando antropologia física e DNA. Tese. Universidade de São Paulo, São Paulo, Brasil.

Cossellu, G., De Luca, S., Biagi, R., Farronato, G., Cingolani, M., Ferrante, L. \& Cameriere, R. (2015). Reliability of frontal sinus by cone beam-computed tomography (CBCT) for individual identification. Radiol Med., 120(12), 1130-6.

Cox, M., Malcolm, M. \& Fairgrieve, S. I. (2009). A new digital method for the objective comparison of frontal sinuses for identification. J Forensic Sci., 54(4), $761-72$.

David, M. P. \& Saxena, R. (2010). Use of frontal sinus and nasal septum patterns as an aid in personal identification: A digital radiographic pilot study. $J$ Forensic Dent Sci., 2 (2), 77-80.

Demiralp, K. O., Cakmak, S. K., Aksoy, S., Bayrak, S., Orhan, K. \& Demir, P. (2019). Assessment of paranasal sinus parameters according to ancient skulls' gender and age by using cone-beam computed tomography. Folia Morphol., 78(2), 344-350.

Dostalova, T., Eliasova, H., Seydlova, M. \& Broucek, J. V. (2012). The application of CamScan 2 in forensic dentistry. J Forensic Leg Med., 19(7), 373-80.

Duque, C.S. \& Casiano, R.R. (2005). Surgical Anatomy and Embryology of the Frontal Sinus. In:Kountakis SE, Senior BA, Draf W, editors. The Frontal Sinus. Berlin/Heidelberg: Springer-Verlag, 21-31. http://link.springer.com/10.1007/3-540-27607-6_3.

Ebrahimnejad, H., Zarch, S. H. \& Langaroodi, A. J. (2016). Diagnostic efficacy of digital waters' and Caldwell's radiographic views for evaluation of sinonasal area. J of Dentistry (Tehran), 13(5), 357-364.

Etemadi, S., Seylavi, G. \& Yadegari, A. (2017). Correlation of the Maxillary Sinus Volume with Gender and Some of Craniofacial Indices Using Cone Beam Computed Tomography. Biosc.Biotech.Res.Comm., 10(3).

Falguera, J. R., Pereira, S. \& Marana, A. N. (2008). Frontal sinus recognition for human identification. Biometric Technology For Human Identification. Proceedings of SPIE - The International Society for Optical Engineering, S9440-S9440.

Farias Gomes, A., Oliveira, G. T., Yamasaki, M. C., Groppo, F. C., Neto F. H. \& Possobon, R. F. (2019). Development and validation of a formula based on maxillary sinus measurements as a tool for sex estimation: a cone beam computed tomography study. Int J Legal Med., 133(4), 1241-1249.

Fatterpekar, G. M., Delman, B. N. \& Som, P. M. (2008). Imaging the paranasal sinuses: Where we are and where we are going. Anat Rec., 291(11), 1564-72. 
Fernandes, C. M. S. (2010). Análise das reconstruções faciais forenses digitais caracterizadas utilizando padrões de medidas lineares de tecidos moles da face de brasileiros e estrangeiros. Tese. Universidade de São Paulo, São Paulo, Brasil.

Fisiologia e Anatomia Endoscópica Nasossinusal. (2011). http://www.otorrinousp.org.br/imageBank/seminarios/seminario_73.pdf.

França, G. V. (2017). Medicina Legal. Guanabara Koogan.

Franklin, D., O’Higgins, P., Oxnard, C. E. \& Dadour, I. (2006). Determination of sex in South African blacks by discriminant function analysis of mandibular linear dimensions: a preliminary investigation using the Zulu local population. Forensic Sci Med Pathol., 2, 263-8.

Franklin, D., O’Higgins, P., Oxnard, C. E. \& Dadour, I. (2008). Discriminant function sexing of the mandible of Indigenous South Africans. Forensic Sci Int., $179,84 . e 1-5$.

Gallup, A. C. \& Hack, G. D. (2011). Human paranasal sinuses and selective brain cooling: A ventila- tion system activated by yawning? Medical Hypotheses, $77(6), 970-973$

Garcia, C. S. (2014). Avaliação do seio maxilar no estudo do dimorfismo sexual utilizando imagens por Tomografia Computadorizada de Feixe Cônico. Conclusão de curso. Universidade Estadual de Campinas, Piracicaba, São Paulo, Brasil.

Gioster-Ramos, M. L., Silva, E. C. A., Nascimento, C. R., Fernandes, C. M. S. \& Serra, M. C. (2021) Técnicas de identificação humana em Odontologia Legal. Research, Society and Developmen, 10(3), e20310313200.

Gulec, M., Tassoker, M., Magat, G., Lale, B., Ozcan, S., \&Orhan, K. (2020). Three-dimensional volumetric analysis of the maxillary sinus: a cone-beam computed tomography study. Folia Morphol (Warsz), 79(3), 557-562.

Harnsberger, H. R., Babbel, R. W. \& Davis, W. L. (1991). The major obstructive inflammatory patterns of the sinonasal region seen on screening sinus computed tomography. Semin Ultrasound CT MR, 12, 541-560.

Hishmat, A. M., Michiue, T., Sogawa, N., Oritani, S., Ishikawa, T., Hashem, M. A. \& Moeda, H. (2014). Efficacy of automated three-dimensional image reconstruction of the femur from postmortem computed tomography data in morphometry for victim identification. Legal Medicine, 16, 114-117.

Hungria, H. (2000). Otorrinolaringologia. Guanabara-Koogan.

Interpol. (2018). Disaster Victim Identification Guide. https://www.interpol.int/How-we-work/Forensics/Disaster-Victim-Identification-DVI.

Kanthem, R. K., Guttikonda, V. R., Yeluri, S. \& Kumari, G. (2015). Sex determination using maxillary sinus. J Forensic Dent Sci. 7 (2), $163-7$.

Keir, J. (2009). Why do we have paranasal sinuses? The Journal of Laryngology \& Otology. 123(1), 4-8.

Kim, D. I., Lee, U. Y., Park, D. K., Kim, Y. S., Han, K. H., Kim, K. H. \& Han, S. H. (2006). Morphometrics of the hyoid bone for human sex determination from digital photographs. J Forensic Sci. 51(5), 979-84.

Kim, D. I., Lee, U. Y., Park, S. O., Kwak, D. S. \& Han, S. H. (2013). Identification using frontal sinus by three-dimensional reconstruction from computed tomography. J Forensic Sci, 58, 5.

Klales, A. R. \& Kenyhercz, M. W. (2015). Morphological Assessment of Ancestry Using Cranial Macromorphoscopics. J. Forensic Sci., 60 (1), 13-20.

Kuan, E. C. \& Palmer, J. N. (2021). Endoscopic Surgery of the Orbit. Elsevier.

Kuhnen, B., Fernandes, C. M. S., Barros, F., Scarso Filho, J., Gonçalves, M., \& Serra, M. C. (2021). Facial soft tissue thickness of Brazilian living subadults. A Cone-Beam Computed Tomography study. Forensic Imaging. 200434.

Laine, F. J. \& Smoker, W. R. K. (1992). Osteomeatal unit and endoscopic surgery: anatomy, variations, and imaging findings in inflammatory diseases. Am J Roentgenol., 159, 849-857.

Lee, W. T., Kuhn, F. A. \& Citardi, M. J. (2004). 3D computed tomographic analysis of frontal recess anatomy in patients without frontal sinusitis. Otolaryngol Head Neck Surg., 131, 164-73.

Li, Y., Xu, C., Yu, D., Xiong, T., Zhao, H., Xue, H., Liang, W. B., Deng, Z. H. \& Zhang, L. (2021). Computer-aided superimposition of the frontal sinus via 3D reconstruction for comparative forensic identification. Int J Legal Med.

Liang, X., Jacobs, R., Hassan, B., Li, L., Pauwels, R., Corpas, L., Souza, P. C., Martens, W., Shahbazian, M., Alonso, A. \& Lambrichts, I. (2010). A comparative evaluation of cone beam computed tomography (CBCT) and multi-slice CT (MSCT) Part I. On subjective image quality. Eur J Radiol., 75(2), 265-9.

Mafee, M. F. (1991). Endoscopic sinus surgery: role of the radiologist. Am J Neuroradiol., 12, 855-860.

Marques, J. A. M., Musse, J. O., Gois, B. C., Galvão, L. C. C. \& Paranhos, L. R. (2014). Cone-beam Computed Tomography Analysis of the Frontal Sinus in Forensic Investigation. Int. J. Morphol., 32(2), 660-665.

Mohamed, S. A., Abdullah, E. M., Said, A. M. \& Ahmed, A. E. (2020). Human sex identification from frontal and maxillary air sinuses using CT scan. The Egyptian Journal of Forensic Sciences and Applied Toxicology, 20(2), 31-43.

Moore, K. \& Ross, A. (2017). Frontal Sinus Development and Juvenile Age Estimation. Anat Rec (Hoboken). 300(9), $1609-1617$.

Musse, J. O. (2009). Identificação humana através da análise do seio maxilar em radiografias panorâmicas. Tese. Faculdade de Odontologia da Universidade de São Paulo, São Paulo, São Paulo, Brasil 
Musse, J. O., Marques, J. A. M., Boas Vilas, C. D. F., Sousa, R. S. V. \& Oliveira, R. N. (2011). Importância pericial das radiografias panorâmicas e da análise odontológica para identificação humana: relato de caso. Rev Odontol UNESP, 40(2), 108-111.

Musse, J. O., Marques, J. A. M. \& Oliveira, R. N. (2009). Contribuição da análise do seio maxilar para a identificação humana. Saúde, Ética \& Justiça,14(2), 65-76.

Najem, S., Safwat, W., Elaziz, R. \& Gaweesh, Y. (2020). Maxillary sinus assessment for gender and age determination using Cone Beam Computed Tomography in an Egyptian sample. Alexandria Dental J., 20, 1-22.

Nerad, J. A. (2021). Techniques in Ophthalmic Plastic Surgery. Elsevier.

Neves, I. S. R., Santiago, A. P. A. C. S., Silva, M. I. T. \& Oliveira, E. R. M. (2021). Rugoscopia palatina e seus desafios na identificação humana: uma revisão integrativa. Research, Society and Development, 10, 4, e23810414090.

Nikam, S. S., Gadgil, R. M., Bhoosreddy, A. R., Shah, K. R. \& Shirsekar, V. U. (2015). Personal identification in forensic science using uniqueness of radiographic image of frontal sinus. J Forensic Odontostomatol., 33(1), 1-7.

Oliveira, J. M., Alonso, M. B., Sousa, E., Tucunduva, M. J., Fuziy, A., Scocate, A. C. \& Costa, A. L. (2017). Volumetric study of sphenoid sinuses: anatomical analysis in helical computed tomography. Surg Radiol Anat., 39(4), 367-374.

Oliveira, J. X., Perrella, A., Santos, K. C. P., Sales, M. A. O. \& Cavalcanti, M. G. P. (2009). Accuracy assessment of human sphenoidal sinus volume and area measure and its relationship with sexual dimorphism using the 3D-CT. J.Health Sci. Inst., 27(4).

Orhan, K., Aksoy, S. \& Oz, U. (2017). CBCT Imaging of Paranasal Sinuses and Variations, Paranasal Sinuses. https://www.intechopen.com/books/paranasalsinuses/cbct-imaging-of-paranasal-sinuses-and-variations.

Ousley, S. D., Jantz, R. \& Freid, F. (2009). Understanding race and human variation: why forensic anthropologists are good at identifying race. Am. J. Phys. Anthropol., 139, 68-76.

Özer, C. M., Atalar, K., Öz, I.I., Toprak, S. \& Barut, Ç. (2018). Sphenoid Sinus in Relation to Age, Gender, and Cephalometric Indices. J Craniofac Surg., 29(8), $2319-2326$

Paknahad, M., Shahidi, S. \& Zarei, Z. (2017). Sexual Dimorphism of Maxillary Sinus Dimensions Using Cone-Beam Computed Tomography. J Forensic Sci., 62(2), 395-398.

Passalacqua, N. V. (2009). Forensic age-at-death estimation from the human sacrum. J. Forensic Sci., 52 (2), $255-262$.

Patil, N., Karjodkar, F. R., Sontakke, S., Sansare, K. \& Salvi, R. (2012). Uniqueness of radiographic patterns of the frontal sinus for personal identification. Imaging Sci Dent., 42(4), 213-7.

Pereira, A. S., Shitsuka, Dorlivete Moreira Parreira, F. J. \& Shitsuka, R. (2018). Metodologia da Pesquisa Científica - Licenciatura em Computação. https://repositorio.ufsm.br/bitstream/handle/1/15824/Lic_Computacao_Metodologia-Pesquisa-Cientifica.pdf?sequence=1 .

Pereira, J. G. D., Santos, J. B. S., Sousa, S. P., Franco, A., Silva, R. H. A. (2021). Frontal sinuses as tools for human identification: a systematic review of imaging methods. Dentomaxillofac Radiol., 9, 20200599.

Perella, A., Rocha, S. S. \& Cavalcanti, M. G. P. (2003). Quantitative analyses of maxillary sinus using computed tomography. J of Applied Oral Science, 11(3), $229-233$.

Pfaeffli, M., Vock, P., Dirnhofer, R., Braun, M., Bolliger, S. A. \& Thali, M. J. (2007). Post-mortem radiological CT identification based on classical ante-mortem X-ray examinations. Forensic Sci Int., 171, 111-117.

Phothikhun, S., Suphanantachat, S., Chuenchompoonut, V. \& Nisapakultorn, K. (2012). Cone-beam computed tomographic evidence of the association between periodontal bone loss and mucosal thickening of the maxillary sinus. J of Periodontology, 83(5), 557-564.

Poorey, V. K. \& Gupta, N. (2014). Endoscopic and computed tomographic evaluation of influence of nasal septal deviation on lateral wall of nose and its relation to sinus diseases. Indian J Otolaryngol Head Neck Surg., 66(3), 330-5.

Prabhat, M., Rai, S., Kaur, M., Prabhat, K., Bhatnagar, P. \& Panjwani, S. (2016). Computed tomography based forensic gender determination by measuring the size and volume of the maxillary sinuses. J Forensic Dent Sci., 8 (1), 40-6.

Raja, S. V. (2009). Management of the Posterior Maxilla With Sinus Lift: Review of Techniques. J Oral Maxillofac Surg., 67(8), $1730-4$.

Ramos, B.C., Manzi, F. R. \& Vespasiano, A. I. (2021). Volumetric and linear evaluation of the sphenoidal sinus of a Brazilian population, in cone beam computed tomography. J Forensic Leg Med., 77, 102097.

Rani, S. U., Rao, G. V., Kumar, D. R., Sravya, T., Sivaranjani, Y. \& Kumar, M. P. (2017). Age and gender assessment through three-dimensional morphometric analysis of maxillary sinus using magnetic resonance imaging. J Forensic Dent Sci., 9(1), 46.

Riepert, T., Ulmcke, D., Schweden, F. \& Nafe, B. (2001). Identifcation of unknown dead bodies by X-ray image comparison of the skull using the X-ray simulation program FoXSIS. Forensic Sci Int., 117, 89-98.

Ritter, L., Lutz, J., Neugebauer, J., Scheer, M., Dreiseidler, T., Zinser, M.J., Rothamel, D. \& Mischkowski, R.A. (2011). Prevalence of pathologic findings in the maxillary sinus in cone-beam computerized tomography. Oral Surg Oral Med Oral Pathol Oral Radiol Endod, 111(5), 634-40. 
Robles, M., Rando, C. \& Morgan, R. M. (2020). The utility of three-dimensional models of paranasal sinuses to establish age, sex, and ancestry across three modern populations: A preliminary study. Australian J of Forensic Sci.

Ruder, T. D., Kraehenbuehl, M., Gotsmy, W. F., Mathier, S. L. C., Thali, M. J. \& Hatch, G. M. (2012). Radiologic identification of disaster victims: A simple and reliable method using CT of the paranasal sinuses. European Journal of Radiology, 81(2), e132-e138.

Saccucci, M., Cipriani, F., Carderi, S., Di Carlo, G., D'Attilio, M., Rodolfino, D., Festa, F. \& Polimeni A. (2015). Gender assessment through three-dimensional analysis of maxillary sinuses by means of cone beam computed tomography. Eur Rev Med Pharmacol Sci., 19(2), 185-93.

Sathawane, S. R., Sukhadeve, A. V., Chandak, M. R., Lanjekar, A. B. \& Moon, G. V. (2020). Sex determination by maxillary sinus dimensions using conebeam computed tomography and discriminant function: An analytical study. Int J Forensic Odontol., 5, 19-22.

Scarfe, W. C., Farman, A. G. \& Sukovic, P. (2006). Clinical applications of cone-beam computed tomography in dental practice. J Can Dent Assoc., 72, 75- 80.

Scendoni, R., Kelmendi, J., Cossellu, G., Canturk, N., Celik, A.B., Peker, E., Ferrante, L. \& Cameriere, R. (2021). Comparison of Frontal Sinuses for Personal Identification in 3 Populations Using Cameriere's Code Number. The American Journal of Forensic Medicine and Pathology, 42(1), $42-45$.

Schmidt, C. M. (2004). Estimativa da idade e sua importância forense. Dissertação. Universidade Estadual de Campinas, Piracicaba, São Paulo, Brasil.

Scuderi, A. J., Harnsberger, H. R. \& Boyer, R. S. (1993). Pneumatization of the paranasal sinuses: normal features of the importance to the accurate interpretation of the CT scans and MR images. Am J Roentgenol., 160, 1101-1104.

Sherif, N. A. E. H, Sheta, A. A. E. M., Mohamed, E., Rania, K. \& Henaidy, M. F. (2017). Evaluation of the paranasal sinuses dimensions in sex estimation among a sample of adult egyptians using multidetector computed tomography. Journal of Forensic Radiology and Imaging, 11, 33-39.

Sidhu, R., Chandra, S., Devi, P., Taneja, N., Sah, K. \& Kaur, N. (2014). Forensic importance of maxillary sinus in gender determination: A morphometric analysis from Western Uttar Pradesh. India. Eur J Gen Dent., 3, 53-6.

Silva, R. F., Pinto, R. N., Ferreira, G. M. \& Daruge Júnior, E. (2008). Importância das radiografias do seio frontal para identificação humana. Revista Brasileira de Otorrinolaringologia, 74 (5), 798.

Silva, R. F., Prado, F. B., Caputo, I, G, C., Devito, K. L., Botelho, T. L. \& Daruge Júnior, E. (2009). The forensic importance of frontal sinus radiographs. J Forensic Leg Med., 16(1), 18-23.

Silva, R. F., Rodrigues, L. G., Manica, S., Franco, R. P. A. V., \& Franco, A. (2019). Human identification established by the analysis of frontal sinus seen in anteroposterior skull radiographs using the mento-naso technique: a forensic case report. RBOL-Revista Brasileira de Odontologia Legal, 6(1).

Silveira, P. R. (2015). Fundamentos da Medicina Legal. Lumen Juris.

Singh, S., Bhargava, D. \& Deshpande, A. (2013). Dental orthopantomogram biometrics system for human identification. J Forensic Leg Med., 20(5), 399-401.

Soares, C. B., Almeida, M. S., Lopes, P. M., Beltrão, R. V., Pontual, A. A., Ramos-Perez, F. M., Figueroa, J. N. \& Pontual, M. L. (2016). Human identification study by means of frontal sinus imaginological aspects. Forensic Sci Int., 262, 183-9.

Soares, C. B. R. B., Miranda-Viana, M., Pontual, A. A., Ramos-Perez, F. M. M., Perez, D. E. C., Figueiroa, J. N. \& Pontual, M. L. A. (2020). Morphological and dimensional assessment of the maxillary sinus for human identification and sexual dimorphism: A study using CBCT. Forensic Imaging, $23,200409$.

Tambawala, S. S., Karjodkar, F. R., Sansare, K. \& Prakash, N. (2016). Sexual dimorphism of maxillary sinus using cone beam computed tomography. Egyptian Journal of Forensic Sciences, 6 (2), 120-125.

Tatlisumak, E., Ovali, G. Y., Asirdizer, M., Aslan, A., Ozyurt, B., Bayindir, P. \& Tarhan, S. (2008). CT study on morphometry of frontal sinus. Clinical Anatomy, 21, 287-293.

Teixeira, L. C. L., Walewski, L. A., Tolentino, E., Iwaki, L. C. V. \& Mariliani, S. (2020). Three-dimensional analysis of the maxillary sinus for determining sex and age in human identification. Forensic Imaging. 22, 200395.

Tucunduva, M. J. A. P. S. \& Freitas, C. F. (2008). Estudo imaginológico da anatomia da cavidade nasal e dos seios paranasais e suas variações por meio da tomografia computadorizada helicoidal. Revista da Pós Graduação, 15(1), 46-52.

Uthman, A.T., Al-Rawi, N.H., Al-Naaimi, A.S. \& Al-Timimi, J. F. (2011). Evaluation of maxillary sinus dimensions in gender determination using helical CT scanning. J Forensic Sci., 56(2), 403-8.

Uthman, A. T., Al-Rawi, N. H., Al-Naaimi, A. S., Tawfeeq, A. S. \& Suhail, E. H. (2010). Evaluation of frontal sinus and skull measurements using spiral CT scanning: An Aid in unknown person identification. Forensic Sci Int., 197, 124.e1-124.e7.

Vanrell, J. P. (2019). Odontologia Legal e Antropologia Forense. Guanabara Koogan.

Xavier, T. A., Terada, A. S. S. D. \& Silva, R. H. A. (2015). Forensic application of the frontal and maxillary sinuses: A literature review. J Forensic Radiol Imaging, 3 (2), 105-10.

Yoshino, M., Miyasaka, S., Sato, H. \& Seta, S. (1987). Classification system of frontal sinus patterns by radiography. Its application to identification of unknown skeletal remains. Forensic Sci Int., 34(4), 289-299.

Zhao, H., Li, Y., Xue, H., Deng, Z. H., Liang, W. B. \& Zhang, L. (2021). Morphological analysis of three-dimensionally reconstructed frontal sinuses from Chinese Han population using computed tomography. Int J Legal Med., 135, 1015-1023.

Zinreich, S. J. (1998). Functional anatomy and computed tomography imaging of the paranasal sinuses. Am J Med Sci. 361, 2-12. 